IIIIIIIIIIIIIIIIIIIIIIIIIIIIIIIIIII

Original Article

IIIIIIIIIIIIIIIIIIIIIIIIIIIIIIIIII

\title{
Anti-androgenic activity of procymidone and its metabolites
}

\author{
Yoshitaka Tomigahara,* Noriyuki Suzuki, Hirokazu Tarui, \\ Koichi Saito and Hideo Kaneko \\ Environmental Health Science Laboratory, Sumitomo Chemical Co., Ltd., \\ 3-1-98, Kasugade-Naka, Konohana-ku, Osaka 554-8558, Japan
}

(Received June 13, 2014; Accepted October 21, 2014)

\begin{abstract}
Procymidone $\left(\right.$ Similex $\left.^{\circledR}\right)$ is a fungicide with a weak anti-androgenic activity. The anti-androgenic activity and androgen receptor (AR)-binding activity of procymidone and its six metabolites were evaluated. Anti-androgenic activity was determined in HeLa cells transiently transfected with an AREx3-luciferase reporter and full-length human or rat AR expression vectors (antiandrogen assay). AR-binding activity was determined by a competitive ligand-binding assay based on a fluorescence polarization method (AR-binding assay). It was clear that procymidone, its hydroxylated metabolite $\left(\mathrm{PCM}-\mathrm{CH}_{2} \mathrm{OH}\right)$, and their imide linkage-cleaved compounds ( $\mathrm{PCM}-\mathrm{NH}-\mathrm{COOH}$ and $\mathrm{PA}-\mathrm{CH}_{2} \mathrm{OH}$ ) have anti-androgenic activity and AR-binding activity, and procymidone has the highest activity among these compounds. There were no differences between rats and humans regarding the activities of procymidone and the metabolites. The activity of procymidone was 20-70 times lower than that of hydroxyflutamide, which is a potent anti-androgen. The results indicate that the anti-androgenic activities of procymidone and its metabolites are very weak. @ Pesticide Science Society of Japan

Keywords: species differences, anti-androgenic activity, metabolites, metabolism, rat, human.

Electronic supplementary materials: The online version of this article contains supplementary materials (Supplemental Figures S1, S2 and S3), which are available at http://www.jstage.jst.go.jp/browse/jpestics/.
\end{abstract}

\section{Introduction}

Procymidone (Similex ${ }^{\circledR}$ ) is a fungicide with both protective and curative potential used to control plant diseases such as fruit rots; gray mold on top fruits, vines, and vegetables; and Sclerotinia rot of kidney beans and vegetable crops. ${ }^{1-3)}$ Many toxicity studies were conducted to evaluate the safety of procymidone. When rats were dosed with procymidone at $125 \mathrm{mg} / \mathrm{kg}$, hypospadias was observed in a vast majority of male pups and in all litters, the lowest teratogenic dose level being $37.5 \mathrm{mg} / \mathrm{kg}$ in rats. In contrast, there were no offspring with hypospadias in monkeys or rabbits, even at a dose of $125 \mathrm{mg} / \mathrm{kg}$, the highest dose tested. These results suggested that rats are more sensitive to procymidone exposure than monkeys and rabbits. ${ }^{4)}$ Thus, a series of mechanistic studies related to developmental toxicity was conducted to determine whether there are species differences in anti-androgenic activity, metabolism, excretion, placental transfer, and protein binding among rats, rabbits, monkeys, and humans. In previous reports, findings on the metabolism of procymidone in mammals were documented, and it was clarified that the kinds of metabolites are nearly identical among species. ${ }^{5-7)}$

\footnotetext{
* To whom correspondence should be addressed.

E-mail: tomigahara@sc.sumitomo-chem.co.jp

Published online November 15, 2014

(c) Pesticide Science Society of Japan
}

The metabolic pathways of procymidone in mammals are shown in Fig. 1. Procymidone is hydroxylated at the methyl group of the imide ring. The hydroxylated metabolites $\left(\mathrm{PCM}-\mathrm{CH}_{2} \mathrm{OH}\right.$ and $\mathrm{PA}-\mathrm{CH}_{2} \mathrm{OH}$ ) are then metabolized in two ways: they are either oxidized at the hydroxyl group to form the carboxylated metabolites (PCM-COOH and $\mathrm{PA}-\mathrm{COOH}$ ) or transformed into glucuronide ( $\mathrm{PCM}-\mathrm{CH}_{2} \mathrm{OH}$-glucuronide and $\mathrm{PA}-\mathrm{CH}_{2} \mathrm{OH}-$ glucuronide). The carboxylated metabolites and glucuronide are more hydrophilic and thus more readily excreted. While the anti-androgenic activities of procymidone and its metabolites, PCM- $\mathrm{CH}_{2} \mathrm{OH}$ and $\mathrm{PCM}-\mathrm{COOH}$, were investigated earlier, ${ }^{8)}$ imide linkage-cleaved metabolites, $\mathrm{PA}-\mathrm{CH}_{2} \mathrm{OH}$ and $\mathrm{PA}-\mathrm{COOH}$, and $\mathrm{PCM}-\mathrm{CH}_{2} \mathrm{OH}$-glucuronide, which is a major metabolite in rabbits, were not included. Furthermore, in the previous study, a comparison of anti-androgenic activity between rats and humans was not conducted. The present report deals with the anti-androgenic activity of procymidone and its metabolites and a comparison of anti-androgenic activity between rats and humans. The results of other studies will be described elsewhere.

\section{Materials and Methods}

\section{Compounds}

Procymidone $\left(\mathrm{C}_{13} \mathrm{H}_{11} \mathrm{Cl}_{2} \mathrm{NO}_{2}\right.$, purity: 99.6\%), PCM-NH-COOH $\left(\mathrm{C}_{13} \mathrm{H}_{13} \mathrm{Cl}_{2} \mathrm{NO}_{3}\right.$, purity: 98.6\%), PCM- $\mathrm{CH}_{2} \mathrm{OH}\left(\mathrm{C}_{13} \mathrm{H}_{11} \mathrm{Cl}_{2} \mathrm{NO}_{3}\right.$, purity: $99.9 \%)$, PCM-COOH $\left(\mathrm{C}_{13} \mathrm{H}_{9} \mathrm{Cl}_{2} \mathrm{NO}_{4}\right.$, purity: $\left.96.4 \%\right)$, $\mathrm{PA}-\mathrm{CH}_{2} \mathrm{OH}\left(\mathrm{C}_{13} \mathrm{H}_{13} \mathrm{Cl}_{2} \mathrm{NO}_{4}\right.$, purity: $\left.98.8 \%\right)$, $\mathrm{PA}-\mathrm{COOH}$ 


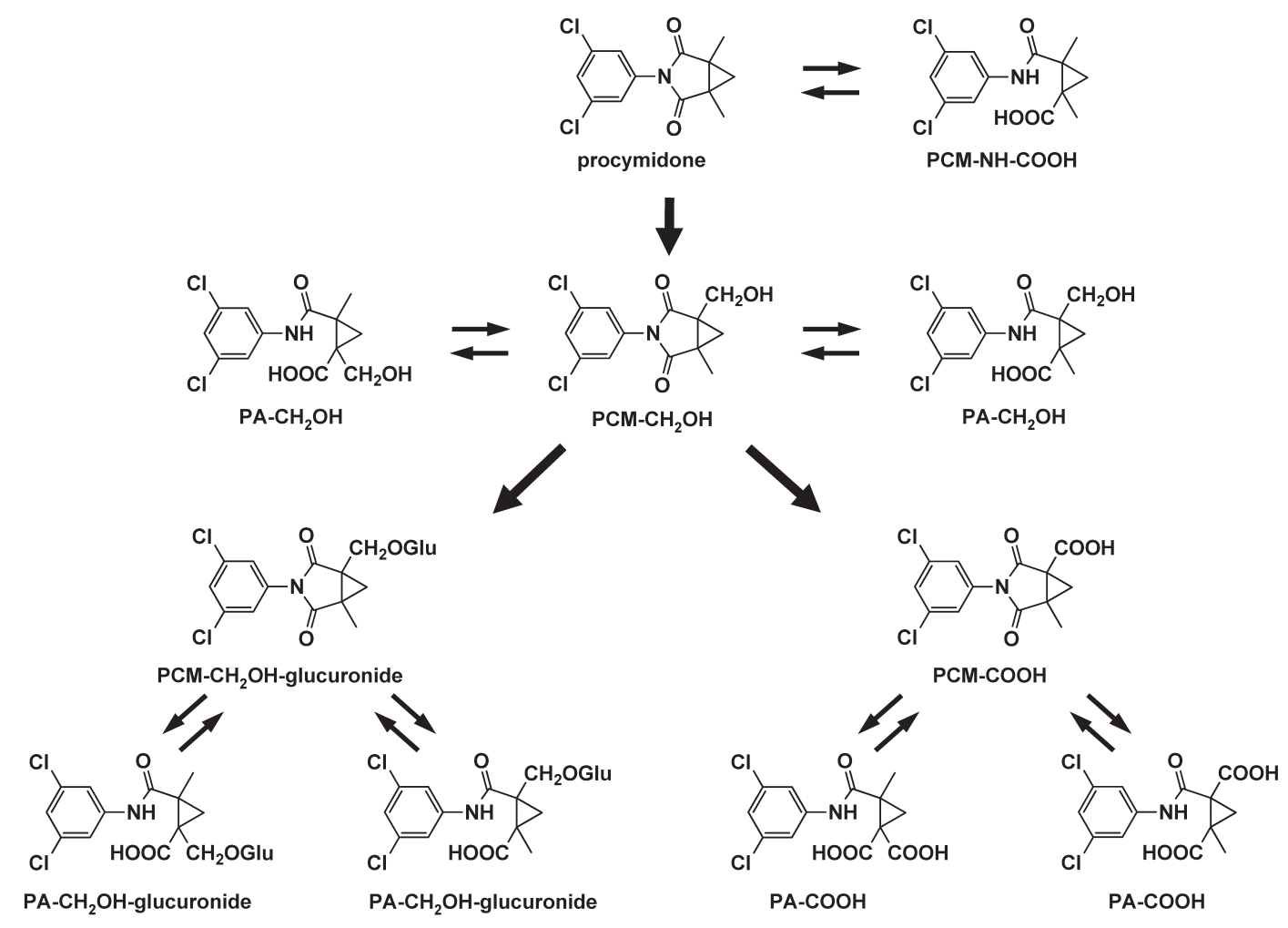

Glu.: glucuronic acid

Fig. 1. Proposed main metabolic pathways of procymidone in mammals.

$\left(\mathrm{C}_{13} \mathrm{H}_{11} \mathrm{Cl}_{2} \mathrm{NO}_{5}\right.$, purity: 96.9\%), and PCM- $\mathrm{CH}_{2} \mathrm{OH}$-glucuronide $\left(\mathrm{C}_{19} \mathrm{H}_{19} \mathrm{Cl}_{2} \mathrm{NO}_{9}\right.$, purity: $\left.99.5 \%\right)$ were synthesized by Sumitomo Chemical Co., Ltd. (Osaka, Japan) and used for anti-androgen assays and AR-binding assays. $5 \alpha$-Dihydrotestosterone (DHT, $\mathrm{C}_{19} \mathrm{H}_{30} \mathrm{O}_{2}$, purity: $\left.\geq 99.0 \%\right)$ and flutamide $\left(\mathrm{C}_{11} \mathrm{H}_{11} \mathrm{~F}_{3} \mathrm{~N}_{2} \mathrm{O}_{3}\right.$, purity: $\geq 98.0 \%)$ were purchased from Fluka Production $\mathrm{GmbH}$ (Buches, Switzerland) and LKT Laboratories, Inc. (Minnesota, USA), respectively. Hydroxyflutamide (HFL, $\mathrm{C}_{11} \mathrm{H}_{11} \mathrm{~F}_{3} \mathrm{~N}_{2} \mathrm{O}_{4}$, purity: $\geq 98.0 \%$ ) was synthesized by Sumitomo Chemical Co., Ltd. DHT was used as an androgen for anti-androgen assays and as a positive control for AR-binding assays. Flutamide and HFL were used as further positive controls for both assays. All compounds were dissolved in dimethyl sulfoxide (DMSO) purchased from Wako Pure Chemical Industries, Ltd. (Osaka, Japan).

\section{Anti-androgen assay}

For the AR-mediated reporter gene assay, the expression vectors 'pRc/RSV-human AR' and 'pRc/RSV-rat AR' were generated by insertion of an RT-PCR-amplified full-length cDNA of human $\mathrm{AR}$ and rat AR with an efficient Kozak's translation initiator sequence into the blunting site of a pRc/RSV vector (Invitrogen, California, USA). The reporter plasmid for AR, 'pGL3-TATAAREx3/luc, was generated by insertion of three copies of AREs derived from rat probasin into a pGL3 basic vector (Promega, Wisconsin, USA) with a mouse metallothionein minimum
TATA promoter. For the control assay, 'pGL3-TK' was generated by insertion of a herpes simplex virus thymidine kinase (HSVTK) promoter into a pGL3 basic vector. Transient transfection was carried out in accordance with a method described previously. ${ }^{9)}$ HeLa cells were routinely maintained in phenol red-free Dulbecco's modified eagle medium (DMEM) containing 10\% charcoal-treated fetal calf serum on $10-\mathrm{cm}$ plates. Twenty-four hours before transfection, $1.1 \times 10^{6}$ cells were seeded in the DMEM mixture per $10-\mathrm{cm}$ plate. For transfection, the cells were incubated with $3 \mu \mathrm{g} /$ plate of 'pRc/RSV-human AR' or 'pRc/RSVrat AR', $3 \mu \mathrm{g} /$ plate of 'pGL3-TATA-AREx3/luc' or $6 \mu \mathrm{g} /$ plate of 'pGL3-TK' (for control assay), and liposome-DNA complexes (lipofectamine, Invitrogen) at $37^{\circ} \mathrm{C}$ for $16 \mathrm{hr}$ and then further incubated for $3 \mathrm{hr}$ after medium change. The transfected cells were dissociated with $2.5 \mathrm{~g} / \mathrm{L}$ trypsin/1 mM EDTA solution (Nacalai Tesque, Kyoto, Japan) and collected. The transfected cells were seeded into plates containing the DMEM mixture with each test chemical and DHT $(50 \mathrm{pM})(n=6)$. The maximum concentrations of chemical were determined on the basis of solubility in medium or (anti-)androgen potential. After approximately $40 \mathrm{hr}$ of incubation at $37^{\circ} \mathrm{C}$, the cells were lysed by adding $50 \mu \mathrm{L} /$ plate of diluted (×2) Steady-Glo Luciferase Assay System (Promega), and after cooling at room temperature for $10 \mathrm{~min}$ luminous intensity was measured using a TopCount NXT microplate detection instrument (Packard BioScience Co., Connecticut, USA). 


\section{AR-binding assay}

A competitive androgen receptor-binding assay was carried out by a fluorescence polarization method using a rat AR Competitor Assay Kit (Green, PanVera, Wisconsin, USA). ${ }^{10)}$ Changes in fluorescence polarization values with each test compound were measured using a multifunctional microplate detection system (ULTRA, Tecan Japan Co., Ltd., Kanagawa, Japan) with suitable $485 \mathrm{~nm}$ excitation and $535 \mathrm{~nm}$ emission filters.

\section{Data analysis}

In the anti-androgen assay, the activity in each concentration of each test compound was calculated using the following equation:

\section{Activity (\%) \\ $=100 \times$ Luciferase activity by chemical with DHT (50 pM)/ Luciferase activity by DHT (50 pM).}

The concentration of each test chemical at which the response in the anti-androgenic activity is $50 \%$ of the response induced by DHT $(50 \mathrm{pM})$ only $\left(\mathrm{IC}_{50}\right)$ was calculated using GraphPad Prism statistical software (GraphPad Software Inc., California, USA).

In the AR-binding assay, the inhibition in each concentration of the test compounds was calculated as follows:

\section{Inhibition (\%) \\ $=100 \times$ Changes of fluorescence polarization value by chemical / Changes of fluorescence polarization value by DHT $(10 \mu \mathrm{M})$.}

The concentration of each test chemical at which the response in the AR-binding activity is $50 \%$ of the response induced by
DHT $(10 \mu \mathrm{M})\left(\mathrm{IC}_{50}\right)$ was calculated using GraphPad Prism statistical software.

The relative anti-androgenic activity and relative AR-binding activity of each test chemical were calculated using the following equations:

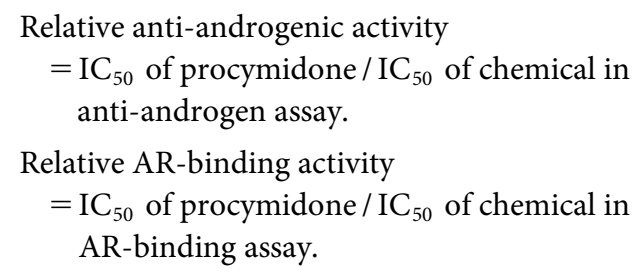

\section{Results}

1. Anti-androgen assay with rat $A R$

Data are shown in Table 1 and Fig. 2. The $\mathrm{IC}_{50}$ values for two typical antagonists, HFL and flutamide, were $5.3 \mathrm{nM}$ and $340 \mathrm{nM}$, respectively. Under the same conditions, procymidone showed clear anti-androgenic activity $\left(\mathrm{IC}_{50}=310 \mathrm{nM}\right)$, and PCM- $\mathrm{CH}_{2} \mathrm{OH}$, a metabolite of procymidone, showed weak activity $\left(\mathrm{IC}_{50}=3.4 \mu \mathrm{M}\right)$. However, no effects of PCM-COOH were observed at concentrations from $1 \mathrm{nM}$ to $30 \mu \mathrm{M}$ (Supplemental Fig. S1). PA- $\mathrm{CH}_{2} \mathrm{OH}$ exhibited weak anti-androgenic activity $\left(\mathrm{IC}_{50}=4.1 \mu \mathrm{M}\right)$, and no effects of $\mathrm{PA}-\mathrm{COOH}$ were observed at concentrations from $1 \mathrm{nM}$ to $30 \mu \mathrm{M}$ (Supplemental Fig. S1). $\mathrm{PCM}-\mathrm{NH}-\mathrm{COOH}$ showed weaker anti-androgenic activity than procymidone $\left(\mathrm{IC}_{50}=1.4 \mu \mathrm{M}\right)$. $\mathrm{PCM}-\mathrm{CH}_{2} \mathrm{OH}$-glucuronide had no effects at concentrations from $1 \mathrm{nM}$ to $30 \mu \mathrm{M}$ (Supplemental Fig. S1). In the control assay, no significant effects were found on

Table 1. $\mathrm{IC}_{50}$ values and relative activities for DHT, HFL, flutamide, procymidone and its metabolites

\begin{tabular}{|c|c|c|c|c|}
\hline \multirow{2}{*}{\multicolumn{2}{|c|}{ Compounds }} & \multicolumn{2}{|c|}{ Anti-androgenic activity } & \multirow{2}{*}{ AR-binding activity } \\
\hline & & Rat & Human & \\
\hline Procymidone & $\begin{array}{c}\mathrm{IC}_{50}(\mu \mathrm{M}) \\
\text { Relative activity }\end{array}$ & $\begin{array}{l}0.31 \\
1.00\end{array}$ & $\begin{array}{l}0.29 \\
1.00\end{array}$ & $\begin{array}{l}12 \\
1.00\end{array}$ \\
\hline $\mathrm{PCM}-\mathrm{CH}_{2} \mathrm{OH}$ & $\begin{array}{c}\mathrm{IC}_{50}(\mu \mathrm{M}) \\
\text { Relative activity }\end{array}$ & $\begin{array}{l}3.4 \\
0.09\end{array}$ & $\begin{array}{l}2.4 \\
0.12\end{array}$ & $\begin{array}{l}26 \\
0.46\end{array}$ \\
\hline $\mathrm{PCM}-\mathrm{COOH}$ & $\begin{array}{c}\mathrm{IC}_{50}(\mu \mathrm{M}) \\
\text { Relative activity }\end{array}$ & $\begin{array}{l}- \\
-\end{array}$ & $\begin{array}{l}- \\
-\end{array}$ & $\begin{array}{l}- \\
-\end{array}$ \\
\hline PCM-NH-COOH & $\begin{array}{c}\mathrm{IC}_{50}(\mu \mathrm{M}) \\
\text { Relative activity }\end{array}$ & $\begin{array}{l}1.4 \\
0.22\end{array}$ & $\begin{array}{l}1.2 \\
0.24\end{array}$ & $\begin{array}{l}100 \\
0.12\end{array}$ \\
\hline $\mathrm{PA}-\mathrm{CH}_{2} \mathrm{OH}$ & $\begin{array}{c}\mathrm{IC}_{50}(\mu \mathrm{M}) \\
\text { Relative activity }\end{array}$ & $\begin{array}{l}4.1 \\
0.08\end{array}$ & $\begin{array}{l}3.5 \\
0.08\end{array}$ & $\begin{array}{r}227 \\
0.05\end{array}$ \\
\hline $\mathrm{PA}-\mathrm{COOH}$ & $\begin{array}{c}\mathrm{IC}_{50}(\mu \mathrm{M}) \\
\text { Relative activity }\end{array}$ & $\begin{array}{l}- \\
-\end{array}$ & $\begin{array}{l}- \\
-\end{array}$ & $\begin{array}{l}- \\
-\end{array}$ \\
\hline PCM- $\mathrm{CH}_{2} \mathrm{OH}$-glucuronide & $\begin{array}{c}\mathrm{IC}_{50}(\mu \mathrm{M}) \\
\text { Relative activity }\end{array}$ & $\begin{array}{l}- \\
-\end{array}$ & $\begin{array}{l}- \\
-\end{array}$ & $\begin{array}{l}- \\
-\end{array}$ \\
\hline HFL (hydroxyflutamide) & $\begin{array}{c}\mathrm{IC}_{50}(\mu \mathrm{M}) \\
\text { Relative activity }\end{array}$ & $\begin{array}{l}0.0053 \\
58.49\end{array}$ & $\begin{array}{l}0.0044 \\
65.91\end{array}$ & $\begin{array}{r}0.57 \\
21.05\end{array}$ \\
\hline Flutamide & $\begin{array}{c}\mathrm{IC}_{50}(\mu \mathrm{M}) \\
\text { Relative activity }\end{array}$ & $\begin{array}{l}0.34 \\
0.91\end{array}$ & $\begin{array}{l}0.23 \\
1.25\end{array}$ & $\begin{array}{c}10.6 \\
1.13\end{array}$ \\
\hline DHT (Dihydrotestosterone) & $\begin{array}{c}\mathrm{IC}_{50}(\mu \mathrm{M}) \\
\text { Relative activity }\end{array}$ & $\begin{array}{l}\text { N.E. } \\
-\end{array}$ & $\begin{array}{l}\text { N.E. } \\
-\end{array}$ & $\begin{array}{c}0.039 \\
307.69\end{array}$ \\
\hline
\end{tabular}

Relative anti-androgenic activity and relative AR-binding activity of procymidone were defined as 1.00. N.E.: not examined, —: no activity. 


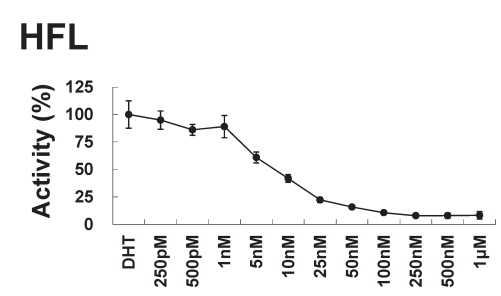

\section{Flutamide}

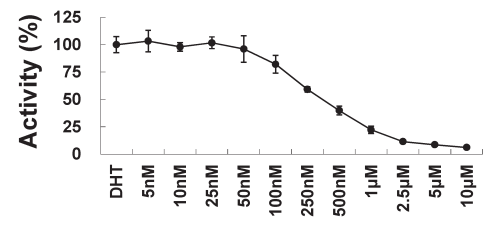

\section{Procymidone}

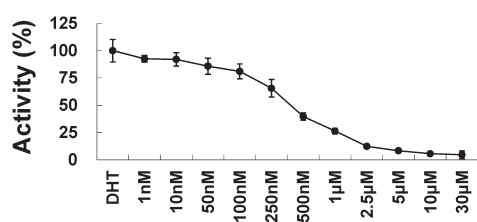

$\mathrm{PCM}-\mathrm{CH}_{2} \mathrm{OH}$

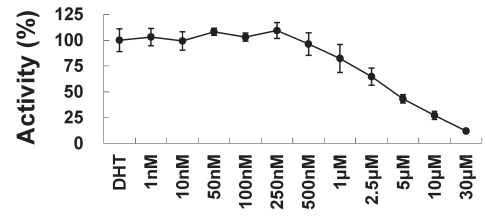

PCM-NH-COOH

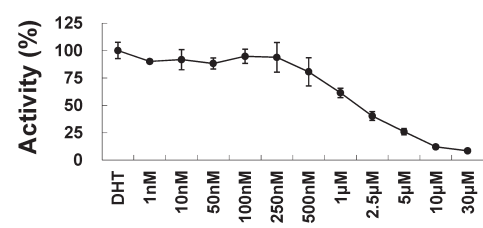

$\mathrm{PA}-\mathrm{CH} 2 \mathrm{OH}$

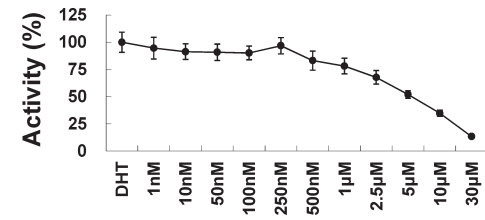

Fig. 2. Anti-androgenic activity of HFL, flutamide, and procymidone and its metabolites (having activity) in the anti-androgen assay using the rat androgen receptor (mean \pm S.D., $n=6$ ).

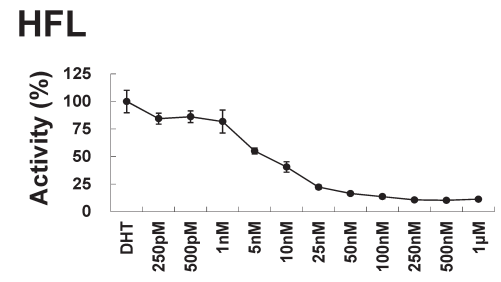

\section{Flutamide}

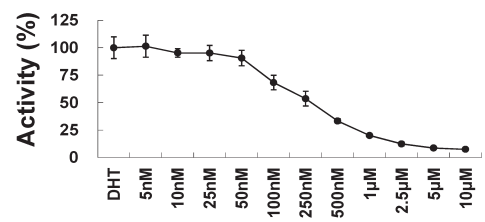

Procymidone

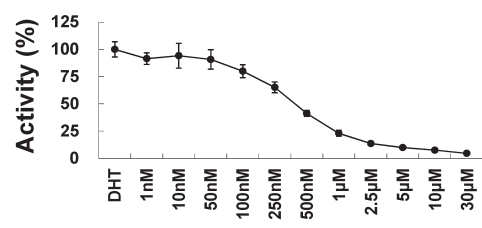

\section{$\mathrm{PCM}-\mathrm{CH}_{2} \mathrm{OH}$}

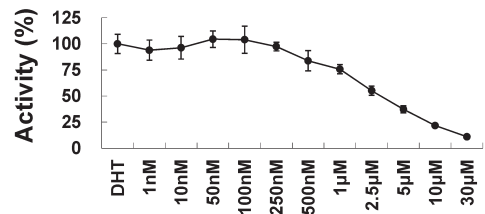

PCM-NH-COOH

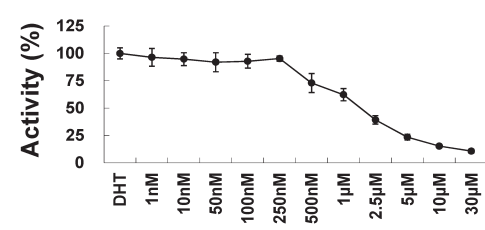

\section{$\mathrm{PA}-\mathrm{CH}_{2} \mathrm{OH}$}

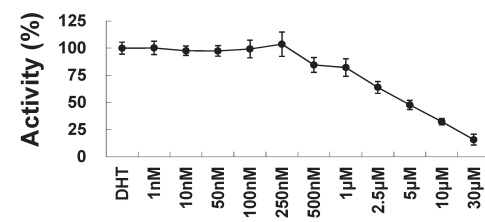

Fig. 3. Anti-androgenic activity of HFL, flutamide, and procymidone and its metabolites (having activity) in the anti-androgen assay using the human androgen receptor (mean \pm S.D., $n=6$ ).

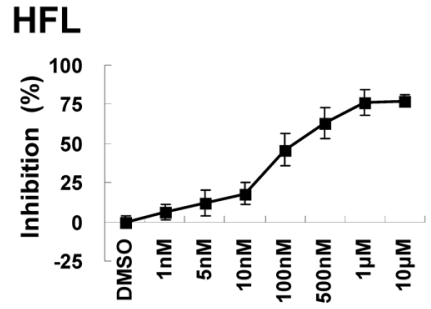

Flutamide

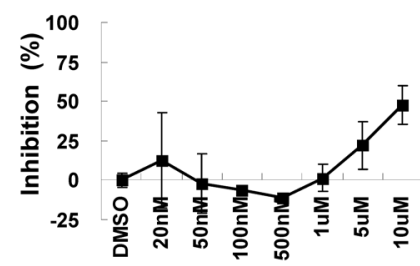

Procymidone

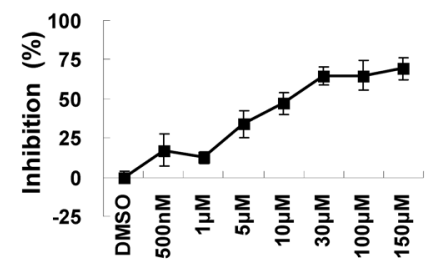

$\mathrm{PCM}-\mathrm{CH}_{2} \mathrm{OH}$

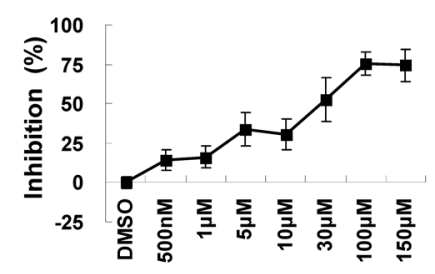

PCM-NH-COOH

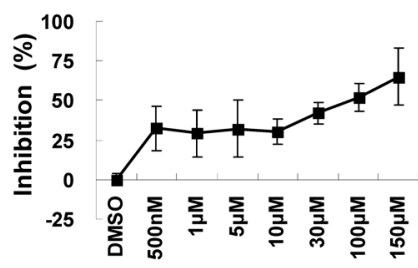

\section{$\mathrm{PA}-\mathrm{CH}_{2} \mathrm{OH}$}

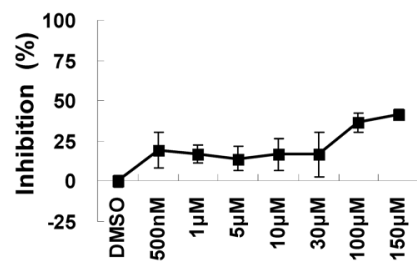

Fig. 4. AR-binding activity of HFL, flutamide, and procymidone and its metabolites (having activity) in the AR-binding assay (mean \pm S.D., $n=3$ ). 
treatment with procymidone or any of the tested metabolites at the concentrations of $1 \mathrm{nM}$ to $30 \mu \mathrm{M}$ (Supplemental Fig. S1). In the assay, neither procymidone nor any of the tested metabolites caused any obvious cytotoxicity.

\section{Anti-androgen assay with human AR}

Data are shown in Table 1 and Fig. 3. The $\mathrm{IC}_{50}$ values for HFL and flutamide were $4.4 \mathrm{nM}$ and $230 \mathrm{nM}$, respectively. Under the same conditions, procymidone showed clear anti-androgenic activity $\left(\mathrm{IC}_{50}=290 \mathrm{nM}\right)$, and PCM-CH${ }_{2} \mathrm{OH}\left(\mathrm{IC}_{50}=2.4 \mu \mathrm{M}\right)$, PCM$\mathrm{NH}-\mathrm{COOH}\left(\mathrm{IC}_{50}=1.2 \mu \mathrm{M}\right)$, and $\mathrm{PA}-\mathrm{CH}_{2} \mathrm{OH}\left(\mathrm{IC}_{50}=3.5 \mu \mathrm{M}\right)$ showed somewhat weak activity. $\mathrm{PCM}-\mathrm{COOH}, \mathrm{PA}-\mathrm{COOH}$, and PCM- $\mathrm{CH}_{2} \mathrm{OH}$-glucuronide had no effects at concentrations from $1 \mathrm{nM}$ to $30 \mu \mathrm{M}$ (Supplemental Fig. S2). In the control assay, no significant effects were found on treatment with procymidone or any of the tested metabolites at concentrations of $1 \mathrm{nM}$ to $30 \mu \mathrm{M}$ (Supplemental Fig. S2). Neither procymidone nor any of the tested metabolites showed any cytotoxicity.

\section{AR-binding assay}

Data are shown in Table 1 and Fig. 4. Significant dose-dependent changes in fluorescence polarization were detected with DHT, HFL, and flutamide, indicating that these chemicals can bind to AR with androgenic (DHT) or anti-androgenic (HFL and flutamide) effects. The $\mathrm{IC}_{50}$ values for DHT, HFL, and flutamide were $39 \mathrm{nM}, 570 \mathrm{nM}$, and $10.6 \mu \mathrm{M}$, respectively. Procymidone showed dose-dependent AR-binding activity $\left(\mathrm{IC}_{50}=12 \mu \mathrm{M}\right)$, and $\mathrm{PCM}-\mathrm{CH}_{2} \mathrm{OH}$ showed weak AR-binding activity $\left(\mathrm{IC}_{50}=26 \mu \mathrm{M}\right)$. $\mathrm{PA}-\mathrm{CH}_{2} \mathrm{OH}$ demonstrated weak but not negligible AR-binding activity at concentrations from 100 to $150 \mu \mathrm{M}\left(\mathrm{IC}_{50}=227 \mu \mathrm{M}\right)$. PCM-NH-COOH showed weak AR-binding activity at concentrations from 10 to $150 \mu \mathrm{M}$ $\left(\mathrm{IC}_{50}=100 \mu \mathrm{M}\right)$. PCM-COOH, PA-COOH, and PCM-CH $\mathrm{CH}_{2} \mathrm{OH}$ glucuronide had no effects at concentrations from $100 \mathrm{nM}$ to $150 \mu \mathrm{M}$ (Supplemental Fig. S3).

\section{Discussion}

As shown in Table 1, Fig. 2, and Fig. 3, the present evaluation of anti-androgenic activity of procymidone and its metabolites revealed no clear differences between human and rat AR anti-androgen assays. Therefore, it was considered that there are no differences between rats and humans regarding the antiandrogenic activity of procymidone and its metabolites. In the AR-binding assay, we used a fluorescence polarization method that is well established for high-throughput screening of nuclear receptor ligands, instead of conventional binding assays with radioactive ligands. In general, AR-binding assays based on fluorescence polarization are less sensitive than the conventional binding assays (data presented in the manufacturer's description), and significant differences were found between the $\mathrm{IC}_{50}$ values of $\mathrm{AR}$-binding and anti-androgen assays in the present study (Table 1). In the anti-androgen assay, the relative anti-androgen activity of $\mathrm{PCM}-\mathrm{CH}_{2} \mathrm{OH}$ was approximately oneeighth that of procymidone. However, in the AR-binding assay, the activity was about half. The AR-binding assay was conducted under cell-free conditions. On the other hand, the anti-androgen assay was performed with cells. Therefore, it is considered that the difference was caused by the low permeability of PCM$\mathrm{CH}_{2} \mathrm{OH}$ to cells, resulting in reduced activity in the anti-androgen assay. This indicates that the AR-binding results for PCM$\mathrm{CH}_{2} \mathrm{OH}$ might better reflect actual activity (behavior) inside the cell than the results of the anti-androgen assay. Furthermore, a reverse phenomenon was observed for imide linkage-cleaved metabolites (PCM-NH-COOH and $\mathrm{PA}-\mathrm{CH}_{2} \mathrm{OH}$ ). Relative activities were weaker in the AR-binding assay than in the antiandrogen assay. Generally, it has been reported that $\mathrm{pH}$ values within cells (intracellular $\mathrm{pH}$ ) are 0.6-0.7 units lower those outside (in body fluid, such as blood) in all animal species, including humans, and intracellular $\mathrm{pH}$ is approximately 7.0 (the $\mathrm{pH}$ of blood is 7.4). ${ }^{11-13)}$ In our previous study, ${ }^{14)}$ it was demonstrated that the imide (cyclic) compounds (procymidone, PCM$\mathrm{CH}_{2} \mathrm{OH}$, and $\mathrm{PCM}-\mathrm{COOH}$ ) and the corresponding imide linkage-cleaved metabolites (PCM-NH-COOH, PA- $\mathrm{CH}_{2} \mathrm{OH}$, and $\mathrm{PA}-\mathrm{COOH}$, respectively) are in equilibrium and, in cells of tissues, imide linkage-cleaved compounds are easily transformed into the corresponding cyclic compounds (from $\mathrm{PA}-\mathrm{CH}_{2} \mathrm{OH}$ to PCM- $\mathrm{CH}_{2} \mathrm{OH}$ ). Further, it has been demonstrated that under acidic conditions (less than $\mathrm{pH}$ 7.0, for instance: in tissue), imide (cyclic) compounds (procymidone, $\mathrm{PCM}-\mathrm{CH}_{2} \mathrm{OH}$, and PCM$\mathrm{COOH}$ ) are stable, while under alkali conditions (more than $\mathrm{pH}$ 7.4 , for instance: in blood), they are converted to imide linkagecleaved metabolites (PCM-NH-COOH, PA- $\mathrm{CH}_{2} \mathrm{OH}$, and $\mathrm{PA}-$ $\mathrm{COOH}$, respectively). In our anti-androgen assays, $\mathrm{HeLa}$ cells were used and incubated at $37^{\circ} \mathrm{C}$ for $48 \mathrm{hr}$. Therefore, the imide linkage-cleaved metabolites ( $\mathrm{PCM}-\mathrm{NH}-\mathrm{COOH}, \mathrm{PA}-\mathrm{CH}_{2} \mathrm{OH}$, and $\mathrm{PA}-\mathrm{COOH}$ ) would have been transformed into the corresponding cyclic metabolites (procymidone, $\mathrm{PCM}-\mathrm{CH}_{2} \mathrm{OH}$, and $\mathrm{PCM}-\mathrm{COOH}$, respectively) inside the cells. In contrast, a buffer of $\mathrm{pH} 7.4$ was used as a sample solution (cell-free condition) for the AR-binding assay and incubated at room temperature. Therefore, in this reaction, it is considered that the above transformations would rarely occur. Accordingly, the activity of imide linkage-cleaved metabolites is considered to be higher in the anti-androgen assay than in the AR-binding assay. This indicates that the activity of imide linkage-cleaved metabolites in the antiandrogen assay might better reflect actual activity (behavior) inside the cell than the AR-binding assay did, although we must consider cell permeability of the compounds.

Therefore, as the most conservative scenario, to see the actual activity (behavior) of procymidone and its metabolites inside the cell (tissues) after penetration of the cellular membrane of the compounds, it is necessary to judge using a combination of antiandrogen and AR-binding assays. The relative binding affinity values were calculated using the equations below. In addition, AR-binding activity data (rat) were used as human data because there was no difference between human and rat AR anti-androgen assays. 
Table 2. Calculated relative binding affinities of procymidone and its metabolites

\begin{tabular}{|c|c|}
\hline Compounds & Relative binding affinity \\
\hline Procymidone & 1.00 \\
\hline $\mathrm{PCM}-\mathrm{CH}_{2} \mathrm{OH}$ & $0.46^{a)}$ \\
\hline $\mathrm{PCM}-\mathrm{COOH}$ & - \\
\hline $\mathrm{PCM}-\mathrm{NH}-\mathrm{COOH}$ & $0.24^{b)}$ \\
\hline $\mathrm{PA}-\mathrm{CH}_{2} \mathrm{OH}$ & $0.31^{b)}$ \\
\hline $\mathrm{PA}-\mathrm{COOH}$ & - \\
\hline $\mathrm{PCM}-\mathrm{CH}_{2} \mathrm{OH}$-glucuronide & - \\
\hline
\end{tabular}

Relative binding affinity of procymidone was defined as 1.00 . - : no binding affinity, $a$ ) data obtained from the AR-binding assay. $b$ ) data obtained from the equation (described in Discussion).

Relative binding affinity of the cyclic compound $\left(\mathrm{PCM}-\mathrm{CH}_{2} \mathrm{OH}\right)=$ Relative AR-binding activity of $\mathrm{PCM}-\mathrm{CH}_{2} \mathrm{OH}$

Relative binding affinity of the imide linkage-cleaved compound ( $\mathrm{PCM}-\mathrm{NH}-\mathrm{COOH}$ and $\mathrm{PA}-\mathrm{CH}_{2} \mathrm{OH}$ )

$=$ Relative anti-androgenic activity of the compound/ Permeability of the compound

However, because we could not assess compound permeability in this study, we used the permeability of the related cyclic compound as an expedient estimate.

Permeability of the imide linkage-cleaved compound

$=$ Relative anti-androgenic activity of the related cyclic compound / Relative AR-binding activity of the related cyclic compound

Therefore,

Relative binding affinity of the imide linkage-cleaved compound

= Relative anti-androgenic activity of the compound/ Permeability of the related cyclic compound $=$ Relative anti-androgenic activity of the compound / (Relative anti-androgenic activity of the related cyclic compound / Relative AR-binding activity of the related cyclic compound)

The calculated relative binding affinity values based on the above definition are shown in Table 2. Relative binding affinity values for androgen receptors of PCM-NH-COOH, PCM$\mathrm{CH}_{2} \mathrm{OH}$, and $\mathrm{PA}-\mathrm{CH}_{2} \mathrm{OH}$ in cells (tissues) were estimated to be $0.24,0.46$, and 0.31 , respectively, with the binding affinity of procymidone defined as 1.00 .

From our study, it was clear that procymidone, its hydroxylat- ed metabolite $\left(\mathrm{PCM}-\mathrm{CH}_{2} \mathrm{OH}\right)$, and their imide linkage-cleaved compounds (PCM-NH-COOH and $\mathrm{PA}-\mathrm{CH}_{2} \mathrm{OH}$ ) have antiandrogenic activity and AR-binding activity, and procymidone has the highest activity among these compounds. There were no differences between rats and humans regarding the activities of procymidone and the metabolites. The activities of procymidone were 20-70 times lower than those of hydroxyflutamide, which is a potent anti-androgen. The results indicate that the anti-androgenic activities of procymidone and its metabolites are very weak. From the above findings, it was concluded that species differences in developmental toxicity are not attributable to species differences in the affinity for AR. Further, it was speculated that the apparent toxic observations in rats were distinguished from the absence of toxicity in rabbits and monkeys by higher internal exposure of PCM and its metabolites, which have anti-androgenic characteristics.

In the future, we will conduct in vivo studies to determine whether there is a species difference for the production amounts of PCM and its metabolites having anti-androgenic and ARbinding activities.

\section{Acknowledgement}

We thank Norihisa Yamashita for his great assistance.

\section{References}

1) Y. Hisada, M. Maeda, N. Tottori and Y. Kawase: J. Pestic. Sci. 1, 145149 (1976).

2) Y. Hisada, M. Maeda, Y. Kawase and J. Miyamoto: J. Pestic. Sci. 1, 201-206 (1976).

3) Y. Hisada, T. Kato and Y. Kawase: Neth. J. Plant Pathol. 83(S1), 71-78 (1977).

4) FAO and WHO: Joint FAO/WHO Meeting on Pesticide Residues 191, 202-210 (2007).

5) N. Mikami, H. Satogami and J. Miyamoto: J. Pestic. Sci. 4, 165-174 (1979).

6) K. Shiba, H. Kaneko, H. Yoshino, N. Kakuta, K. Iba, I. Nakatsuka, A. Yoshitake, H. Yamada and J. Miyamoto: J. Pestic. Sci. 16, 27-33 (1991).

7) H. Nagahori, M. Matsui, Y. Tomigahara, H. Matsunaga, H. Kaneko and I. Nakatsuka: J. Pestic. Sci. 22, 293-298 (1997).

8) S. Hosokawa, M. Murakami, M. Ineyama, T. Yamada, A. Yoshitake, H. Yamada and J. Miyamoto: J. Toxicol. Sci. 18, 83-93 (1993).

9) R. B. Dickson and M. E. Lippman: Endocr. Rev. 16, 559-589 (1995).

10) R. Bolger, T. E. Wiese, K. Ervin, S. Nestich and W. Checovich: Environ. Health Perspect. 106, 551-557 (1998).

11) Y. Honda: Nippon Rinsho 50, 2011-2015 (1992) (in Japanese).

12) Y. Iino: Nippon Jinzo Gakkai Shi 43, 621-630 (2001) (in Japanese).

13) F. B. Walter: Adv. Physiol. Educ. 28, 160-179 (2004).

14) H. Tarui, J. Abe, Y. Tomigahara, S. Kawamura and H. Kaneko: J. Agric. Food Chem. 57, 10883-10888 (2009). 